ISSN: 2655-6251

\title{
Model of Optimal Zakat Allocation by Using Data Envelopment Analysis Approach
}

Vita Sarasi, Ina Primiana, Dian Masyita, Yunizar

Faculty of Economics and Business, Universitas Padjadjaran

Paper to be presented at International Conference of Zakat 2019

3-4 October, Universitas Padjadjaran, Bandung, Indonesia

\section{ABSTRACT}

An optimization model of allocation of zakat fund and recipients is developed based on the Data Envelopment Analysis - Resource Allocation Model (DEA-RAM). The quantitative method plays an important role in optimal allocation of zakat delivery programs performed by some zakat institutions; that is by reallocation of initial setting of the zakat fund and beneficiaries numbers. It raises the needs of improvements in their recent strategies on the programs by the institutions. Zakat institutions, even the government as regulator, should have a clear focus on the povertyempowerment-based programs in providing needed capitals for poverty empowerment. They are expected to create certain conditions in order to prevent excessive of fund allocation for the charity-based delivery programs.

Keywords: Optimization, Zakat delivery, Resource allocation

\section{INTRODUCTION}

In poverty alleviation, deliveries of zakat as an Islamic philanthropy to the poor and needy in optimal manner are not less important in comparison to a best effort on zakat collection. The zakat delivery should consider a certain equilibrium or trade-off on collected fund allocation between the distribution and empowerment objectives.

Needs of an appropriate allocation model by zakat institutions or BAZNAS could be seen through some considerations. Firstly, they need a tool for implementing a macro level indicator guided by BAZNAS such as ACR (Allocation to Collection Ratio) to an organization or program level. Secondly, they might need a quantifiable indicator on the impacts of zakat delivery, beside socio-economic related, for example the numbers of zakat recipient per program as an indicator of zakat outreach.
Furthermore, an optimal model of zakat allocation plays a significant role in maximizing effectiveness of zakat outreach as well as enhancing efficiency related to the outreach of zakat.

One of significant contributions of zakat is the development of small-medium enterprises (SME) for empowering effort to the poor and needy. As an indication, Yumna \& Clarke (2012) described that the Baitul Maal Muamalat Indonesia (BMMI) became a role model of a licensed Islamic philanthropy institution. The institution conducts various programs or projects on charity bases such as aids for natural disaster and direct support for the poor but focusing on economic empowerment basis. Even, they built a partnership with Islamic Development Bank, some philanthropy foundations, and different private and statebased enterprises. This institution develops a program to provide revolving working 
capital credit for low-income microentrepreneurs who were actively participating in Mosque's activities. The concept is to integrate the economic empowerment efforts with enhancing religious belief of the society (charity based) through philanthropy fund delivery, religious capacity development, and encouraging the beneficiaries to SME development.

Therefore, we will focus on the optimal contribution of philanthropy fund including zakat to poverty empowerment.

\section{LITERATURE REVIEW}

Collection and management of the zakat fund in Indonesia are conducted by one government-based institution followed by similar institution in each province, as well as several private-based institutions in national and provincial levels. Besides, the efforts are held by many informal religionbased institutions, such as some foundations under the management of mosque.

According to Yumna \& Clarke (2012), BAZNAS, the government-based zakat institution in Indonesia, only collected US\$ 2.6 million in 2010, where the national potency of the zakat on household income reaches US\$ 61 trillion.

The problem, however, is why achievement of the fund collecting is so small while potential fund of the Islamic philanthropy is so huge due to the majority of Muslim population in Indonesia. The major problem is mainly about trust, but it is not kind of accountability due to establishment of respective law and regulations, instead of trust on how effective and efficient the management of delivery of fund resources.

The fund delivery of zakat is realized by allocate the fund for entrepreneurial aimed programs beside for charity purposes.
The first allocation is used to productive purposes that are in principle to provide angel and venture capitals to trigger beneficiaries to initiate their SME, so that the Zakat behaves as venture philanthropy. This productive based fund allocation should be determined in optimal way with the allocation for consumptive purposes. These different programs are in line to the Indonesian Law of Zakat Management in 2011. Aimed to reduce poverty, this charity based allocation is still needed to consumptive aids the poor to fulfil their basic needs, e.g. food, health, scholarship. Therefore, optimization of the fund resource allocation is essential in setting up the program portfolio conducted by the zakat institutions.

Indeed, some investigations (e.g., Kasri, 2016) stated the effectiveness to increase welfare of the poor and needy, but they investigated in analysis unit of province or district, so that factors of the increases did not known whether it is due to the zakat solely or it is also influenced by other kinds of supports, such as from governments.

Empowering the poverty through support them in entrepreneurship is believed as the best way, in term of effort on sustainable poverty reduction. Hisrich \& Peters (2002) suggested four stages of the entrepreneurial process namely innovation, triggering event, implementation, and growth, which are respectively aimed to identifying and evaluating the opportunity; developing the business plan; determining the resources required; and managing the resulting enterprise.

According to Yumna \& Clarke (2012) it is needed to combine or integrate the source of SME development capital from the Zakat fund with the one from commercial fund of the Islamic microfinance institutions. By using combined sources of funds, the institution could provide both commercial and social services 
for both extremely and economically active poor clients. The commercial services offer various financial services such as saving products, funding schemes and fee based product for the economically active poor of the population. Meanwhile, the social services are designed to improve the wellbeing of the extremely poor and to increase their capacities and capabilities in conducting productive activities. After having adequate skills, it is expected that some of the extremely poor can start a new microenterprise and escalate to the wealthier group of the poor. In the context of resource allocation, the fund delivery needs optimization of the allocation.

From the three main issues above, the rest of problem is about optimal fund resource allocation to generate numbers of beneficiary as many as possible.

\section{METHODOLOGY}

\section{Quantitative Method based on Data}

In the view of operation management of non-profit organization, resource allocation is part of capacity planning to meet supply, i.e., zakat fund resources, and demand, i.e., the poor and needy as potential beneficiaries of the fund. Implementation of the fund resource allocation by the institutions is an objective-based program portfolio Pennypacker (2008) that is a set of fund delivery programs, which have ranges from consumptive-based charity until productiveventure capital for poverty empowerment such as by triggering them to develop SME.

Investigation on the optimal portfolio resource allocation was conducted by a data-oriented non-parametric optimization method of mathematical programming, namely the Data Envelopment Analysis of Resource Allocation Model (DEA-RAM) introduced by Golany \& Tamir (1995). This method is originally derived from DEA that become a group of tool for measuring relative technical efficiency, which is based on empirical production efficiency in economics (e.g., Charnes, et.al., 1997). In principle, results of the method are set of optimal reallocation of fund resources, given by the recent allocation, with maximum effectiveness while maintaining efficiency. In this method, optimality is indicated by an inefficiency score of 1 . Both DEA-based models were applied by the Solver Add-In embedded in Microsoft Excel.

In this DEA approach, a program of zakat fund delivery can be viewed as a point of Decision Making Unit (DMU) that contains information of a pair allocation of delivered fund and received beneficiary numbers. The pairs are then reallocated in optimal manner by using the DEA-RAM method so that the pairs are maximum, which are indicated by "moving" the respective points toward an efficient frontier.

\section{Method of Data Envelopment Analysis - Resource Allocation Model (DEA-RAM)}

In this DEA approach, a program of zakat fund delivery can be viewed as a point of Decision Making Unit (DMU) that contains information of a pair allocation of delivered fund and received beneficiary numbers. The pairs are then reallocated in optimal manner by using the DEA-RAM method so that the pairs are maximum, which are indicated by "moving" the respective points toward an efficient frontier.

We analyzed that changes of efficiency and effectiveness of fund delivery program through optimal reallocation (i.e., toward previous or recent allocations) would indicate that the previous or recent program indicators are not optimal. In that case, the method would also show a possibility on presence of trade-off condition between efficiency and effectiveness. We also assumed that allocation of the fund for each 
beneficiary was constant and it reflected the strategy of the institution in the delivery of fund resources to reach its mission on poverty reduction. The inverse view is the ratio of beneficiary numbers allocated of each fund unit, which we call as "productivity in philanthropy" that tightly relates to the effectiveness.

Basically both the collected zakat fund and the zakat recipient are justified as zakat resources that should be managed optimally by a zakat institution. In mathematical term, maximizing effectiveness and efficiency of the resource allocation can be represented as that the number of potential output $\left\{y_{i}\right\}$ in all decision making unit $(D M U)(j=1, \ldots ., n)$ that can be fulfilled by allocating resource $\left\{x_{i}\right\}$, $i=1, \ldots, m, j=1 \ldots ., n$. The resource allocation considers some empirical production functions based on data in previous period; it also examines limitation of available resource $\left\{B_{i}\right\}$ in every $D M U$ for each $i \in C$, where $\mathrm{C}$ is controllable resources. As the DMU will be enforced to or near the frontier of empirical production, so the second objective of deciding efficient operational efforts can also be reached.

A set of mathematical formulation represents the above scenario called as $D E A$ $R A M$ Golany \& Tamir, 1995) as follow:

Objective function:

$$
\begin{aligned}
& \underset{j=1}{\operatorname{Maximize} Z} \\
& =\sum_{i}^{n} y_{i}
\end{aligned}
$$

Subject to some constraints:

$$
\begin{aligned}
& \sum_{k=1}^{n} y_{k} \cdot \lambda_{k j} \\
& \geq y_{j} \text { for each } \mathrm{k} \text { and } \mathrm{j}
\end{aligned}
$$

$$
\begin{aligned}
& \sum_{k=1}^{n} x_{i k} \cdot \lambda_{k j} \leq x_{i j} \text { for each } \mathrm{i} \text { and } \mathrm{j} \\
& \sum_{k=1}^{n} \lambda_{k j}=1 \\
& \sum_{k=1}^{n} x_{i j} \leq B_{i} \\
& \lambda_{k j}, x_{i j}, y_{i} \geq 0 \text { for each } \mathrm{k}, \mathrm{j}, \text { and } \mathrm{i}
\end{aligned}
$$

where:

$$
\begin{aligned}
& Z=\text { maximum value of } y \\
& x=\text { zakat fund to be delivered } \\
& y=\text { number of zakat recipient } \\
& \lambda=\text { weights of } x \text { and y variables } \\
& B=\text { total of available zakat fund }
\end{aligned}
$$

Combination of objective function (1) and constraints (2) ensure maximum output target. Constraints (3) and (4) ensure that each identified output will identify feasible and minimum resource allocation. Hence efficient performance will be allowed for $\mathrm{n}$ DMU. Constraint (5) represents a condition that all fund delivered through related programs $(=D M U)$ should be less than or same to the total of available zakat fund. Non-negativity of all variables is described by the constraint (6).

The model also provides additional constraint of assumption that ratio of allocated fund for each recipient does not change during the optimal reallocation. This ratio represents strategy of the institution in the zakat delivery. This model was applied by using Solver Add-In in Microsoft Excel.

\section{Measuring Efficiency and Effectiveness}

In principle, efficiency is measured prior to and after reallocation of zakat resources. Efficiency scores can be provided by using DEA method, which will then be plotted in efficiency space (Figure 1). 


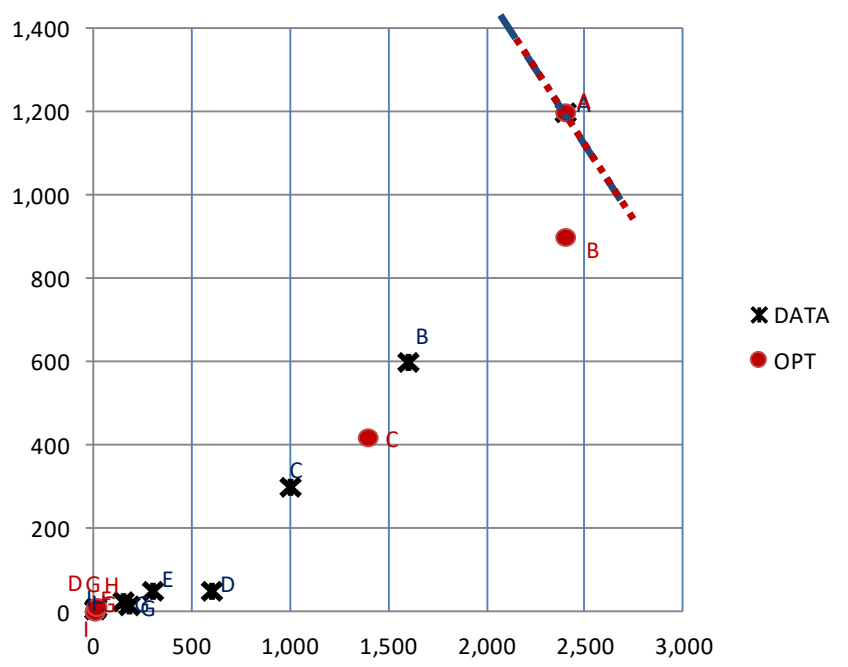

Figure 1. Efficiency space of Zakat Fund and Recipient Number Allocations prior to (blue dots) and after optimal reallocation, where black dotted line is hypothetical efficient Frontier

Meanwhile, effectiveness is indicated by difference between zakat recipient numbers that are counted prior to and after the optimal zakat reallocation.

We applied this methodology to some cases of Zakat institutions in Indonesia to study the effects of a change, i.e., from current resource allocation to optimal one. This case study method is suitable since there is at recent little investigation on fund resource allocation in context of zakat institution in Indonesia. Objective of this preliminary research is to find out what is happening in the changes, to seek new insights as well as to generate ideas and hypotheses for new research (e.g., Runeson \& Hoest, 2009). As suggested by Yin (2003), we emphasize systematically in detailed analysis on the quantitative resource allocation by zakat institutions and programs to the context of providing capital for poverty reduction basis in Indonesia.

\section{RESULTS}

\section{Cases and Data}

We tried to employ the model in two cases that are two different sets of program conducted by two zakat institutions to represent a zakat institution conducting specifically on poverty empowerment efforts.

These all cases were assumed to represent diversity of activities of the Zakat institutions in Indonesia. Case-1 represents a zakat institution which performs both charity and poverty empowerment-type programs (denoted as program A through I; see Table 1). The first type contributes the poor and needy beneficiaries with their basic needs in different aspects such as religion, socio-economic, education, and health. Poverty empowerment as another zakat-type programs were represented through encouraging, coaching, providing an angel and venture capitals for the beneficiaries to develop an SME in farming, stockbreeding, fisheries, trading, and other kinds of livelihood up to their skill and interest. In this context, Case 2 is related to a group of entrepreneurship-based programs in farming, stockbreeding, and small trading enterprise development, respectively, those were conducted by a licensed national-level institution. In each of all cases, we analyzed nine different programs (denoted as program A through I; see Table 2).

We assumed that each institution could manage the fund resource in accordance to type and objectives of programs, which have ranges from a direct (general charity) fund for the beneficiaries, purchases of charitable goods, direct and indirect costs of program, as well as forms of angel and venture capitals for the SME development. Situation of each case was identified by two parameters related to the allocation, i.e.: (1) allocated fund resource as 
an input of the programs, and (2) the beneficiary numbers of the fund as an output. We analyzed current condition by observing patterns of changes on effectiveness and efficiency indicators related to the two parameters by using the DEA-RAM method.

Table 1. Data of Zakat Delivery Programs of Case-1

\begin{tabular}{cccc}
\hline $\begin{array}{c}\text { Zakat } \\
\text { Delivery } \\
\text { Program }\end{array}$ & $\begin{array}{c}\text { Zakat } \\
\text { Fund } \\
\text { Allocation }\end{array}$ & $\begin{array}{c}\text { Recipient } \\
\text { Numbers } \\
\text { (persons) }\end{array}$ & $\begin{array}{c}\text { Fund } \\
\text { Allocated/ } \\
\text { Person }\end{array}$ \\
\hline A & $20.83 \%$ & 52 & 855,92 \\
B & $5.21 \%$ & 54 & 205,29 \\
C & $22.92 \%$ & 569 & 86,35 \\
D & $20.83 \%$ & 804 & 55,56 \\
E & $3.13 \%$ & 130 & 51,48 \\
F & $15.63 \%$ & 1.875 & 17,88 \\
G & $2.08 \%$ & 298 & 14,99 \\
H & $3.13 \%$ & 583 & 11,49 \\
I & $6.25 \%$ & 1.765 & 7,60 \\
& $100.00 \%$ & 6.132 & \\
\hline
\end{tabular}

Table 2. Data of Zakat Delivery Programs of Case-2

\begin{tabular}{cccc}
\hline $\begin{array}{c}\text { Zakat } \\
\text { Delivery } \\
\text { Program }\end{array}$ & $\begin{array}{c}\text { Zakat } \\
\text { Fund } \\
\text { Allocation }\end{array}$ & $\begin{array}{c}\text { Recipient } \\
\text { Numbers } \\
\text { (persons) }\end{array}$ & $\begin{array}{c}\text { Fund } \\
\text { Allocated/ } \\
\text { Person }\end{array}$ \\
\hline A & $3.59 \%$ & 85 & 1,313 \\
B & $4.25 \%$ & 61 & 2,165 \\
C & $5.59 \%$ & 52 & 3,336 \\
D & $6.70 \%$ & 47 & 4,429 \\
E & $16.26 \%$ & 82 & 6,197 \\
F & $20.50 \%$ & 89 & 7,192 \\
G & $21.19 \%$ & 71 & 9,268 \\
H & $12.25 \%$ & 36 & 10,473 \\
I & $9.66 \%$ & 20 & 15,000 \\
& $100.00 \%$ & 542 & \\
\hline
\end{tabular}

\section{Optimal zakat allocation}

The results of resource allocations of Case-1 are presented by Figure 2 and Figure 3 below. At previous, the zakat institution allocated large portion of the fund but for small numbers of beneficiaries in the first two poverty-empowerment-based programs (Program A and B). The optimal reallocation then suggested decreases of the fund allocation for such kind of programs and increases both of fund and beneficiary numbers of the rest five charity-based programs (Program E to I). However, it was unusual that the pattern of optimal reallocation of the numbers of beneficiaries in the charity-based programs were as high as near-maximum, resulting almost empty of the beneficiaries in rest five programs that are based on poverty-empowerment.

We indicated that one or more points were positioned in the efficient frontier, which represented optimality of these pairs of allocation in previous condition. Other points having inefficiency scores of more than 1 are assumed to be in sub-optimal conditions.

Data of Program-C and F showed efficient conditions of the pair allocations of fund and beneficiary numbers, which their points were indicated in the previous efficient frontier. However, optimization then showed reallocation of almost of all programs, so that the-E was finally the maximum efficient and effective program, although the allocation pair of Program-F remained. The three other charity-based programs (i.e., Program-G, H, and I) showed lots of increase of efficiency.

These increases of efficiency of the three previous programs are induced by lower ratios of allocated zakat fund per beneficiary numbers. In other sides, the larger ratios affect worse efficiencies of the reallocated pairs of the four povertyempowerment-based programs (i.e., Program-A to D), which were showed by lowering efficiencies of the four points toward almost zero. 


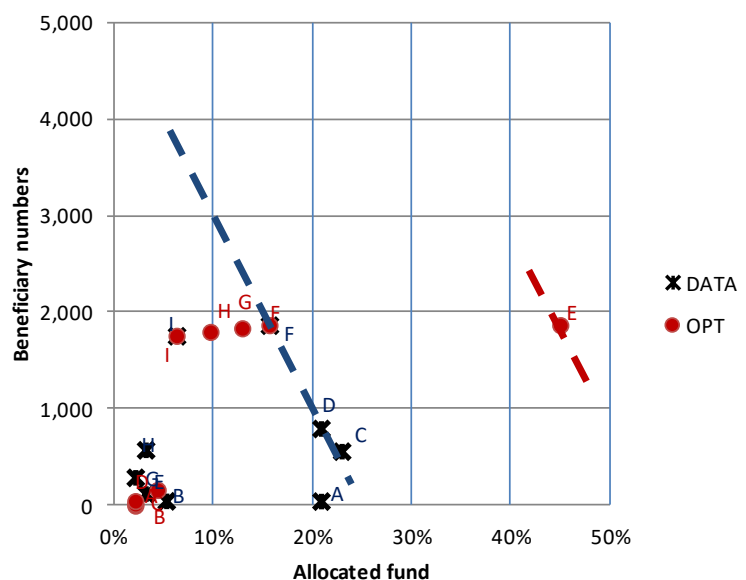

Figure 2. Pairs of allocation of the fund and beneficiary numbers of each program in recent and optimal conditions (note: dashed line is a hypothesized efficient frontier)

Impacts of changes of the ratio of allocated fund-per-zakat-recipient (as an indication by program) on both indicators due to the optimal reallocation are seen in Figure 3 (above and below, respectively).

Charity-based programs that have lower ratios are able to increase their allocated fund as well as zakat recipient numbers. In turn, the povertyempowerment-based programs that have larger ratios indeed should decrease the allocated fund and zakat recipient numbers.

In a different circumstance, Case-2, the zakat institution executed their fund delivery programs that were focused on providing the capitals for development of entrepreneurship as attempts on poverty reduction. Scatter diagrams (Figure 4) showed different spread patterns of allocation pairs of delivery fund and beneficiary numbers. Many of zakat delivery programs of the case showed un-optimized conditions. Next, the DEA-RAM had suggested improvement through fund resource reallocation resulting in increases of both efficiency and effectiveness in all of the three cases. However, the optimization indicated that previous allocations were actually almost optimal as changes of the allocation pairs in optimal condition were not substantial. In addition, the efficient frontier did also not change due to the reallocation.

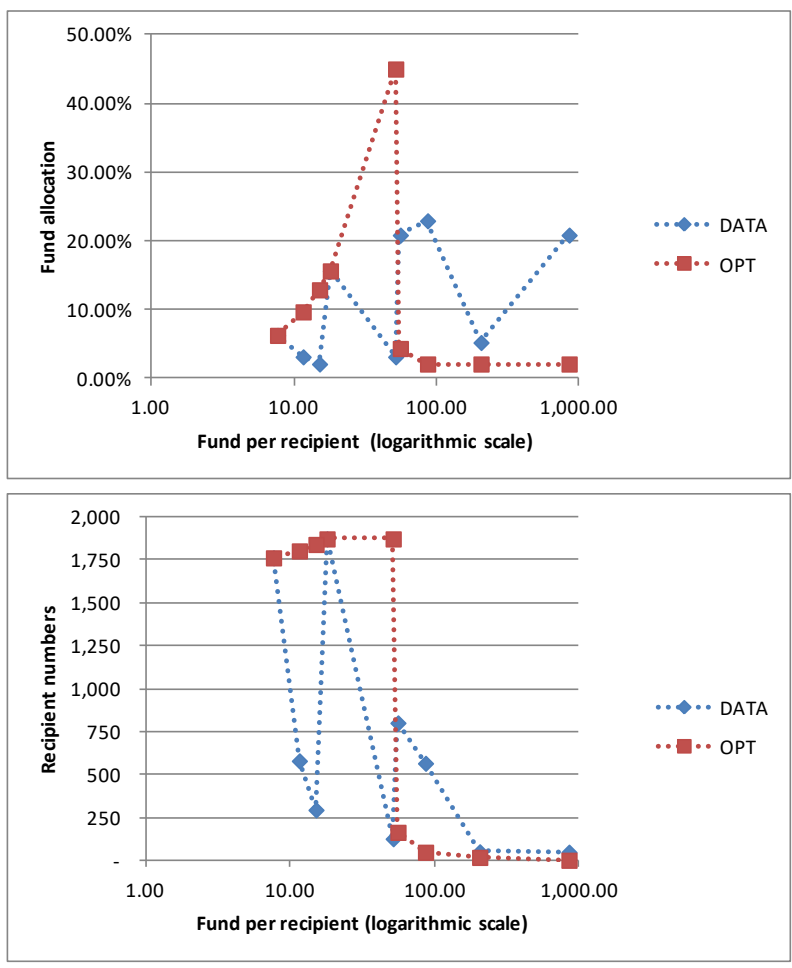

Figure 3. Zakat fund allocation (above) and recipient numbers (below) of Case-1 as function of ratio of fund per recipient

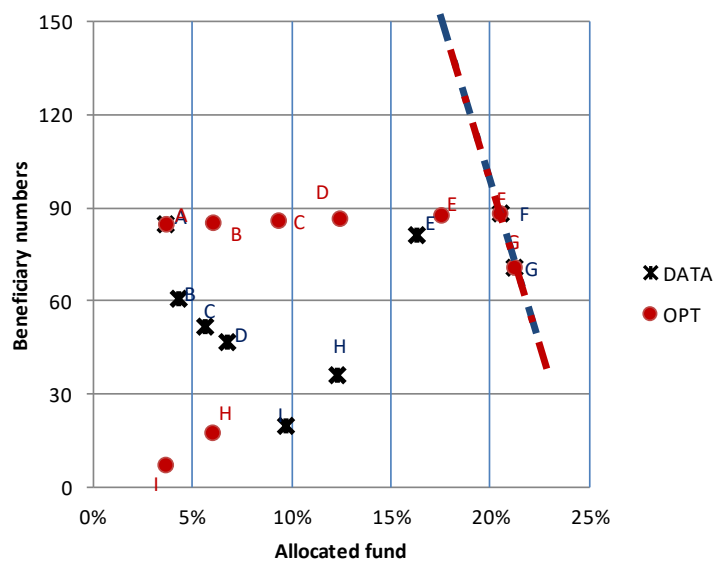

Figure 4. Pairs of allocation of the fund and beneficiary numbers of each program in recent and optimal conditions (note: dashed line is a hypothesized efficient frontier) 
Change of zakat fund distribution over the ratio of fund-per-zakat-recipient indicated by programs as the result of optimal reallocation is seen in Figure 5 (above), while resulted change of zakat recipient is observed in Figure 5 (below).

Impacts of changes of the ratio of allocated fund-per-zakat-recipient as per indicated program on both indicators due to the optimal reallocation are seen in Figure 5 (above and below, respectively).

Again, zakat delivery programs that have lower ratios of allocated fund-perzakat-recipient are able to increase their allocated fund and zakat recipient numbers. However, the zakat delivery programs that have larger ratios indeed should decrease the allocated fund and zakat recipient numbers.
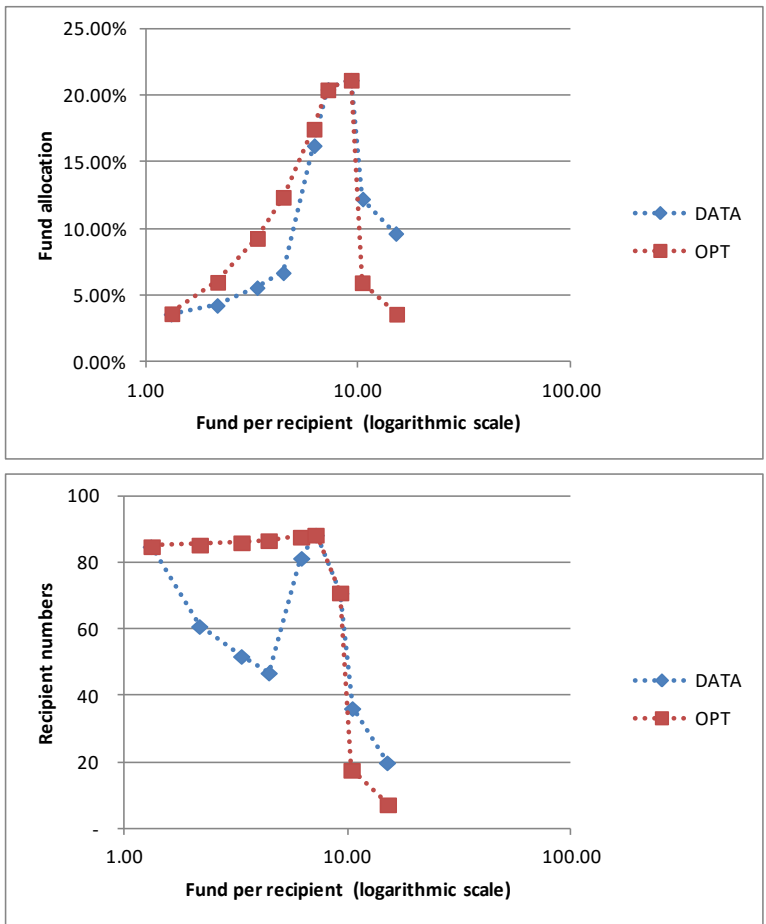

Figure 5. Zakat fund allocation (above) and recipient numbers (below) of Case- 2 as function of ratio of fund per recipient

\section{DISCUSSIONS}

Description of the first of two cases showed that the Zakat institutions typically conducting many different types of zakat programs had not optimally allocate their fund resource into these program portfolio. It is suggested that the institutions should decide their fund delivery programs so that the pairs of allocation of fund and beneficiary numbers of every program will develop optimal efficiency and effectiveness, i.e., onto or at least nearby the developed efficient frontier. However, it was also indicated that these two institutions did not pay much attention on poverty empowerment by providing less capitals for SME development. This is indicated by some DMUs on poverty-empowermentbased programs were far from the efficient frontier, even in optimal reallocation condition, i.e., Program A-D.

The second case had exhibited characteristics of fund and beneficiary allocations in the institutions or program groups that focused on poverty empowerment through provision of needed capitals of SME development. All of the programs should be directed to enhance "productivity in philanthropy" to reach maximum beneficiary numbers given by the allocated fund resource. Trade off may also be occurred when there are needs of program to provide high capital but also need to be endorsed since they have high technology, as an example.

It was proved by some numerical experiments using the DEA-RAM, ideal condition of effective and efficient pairs of allocation were reached when the charitybased programs have less fund resource to provide more beneficiary numbers, whereas the poverty-empowerment-based programs manage on the contrary. Other ideal situation is that the fund resource is allocated homogeneously for all available programs, while beneficiary number allocations of the charity-based programs are more than ones of the poverty- 
empowerment-based programs. In these optimal conditions, the reallocation will create this resource allocation pair relatively unchanged.

However, in the context of support on poverty-reduction-based SME development fewer allocations of beneficiary numbers by the zakat delivery programs are not expected. To this context, the zakat institutions might have clear focus on conducting and allocating their fund resources to solely programs in providing necessary capitals for the SME development.

\section{CONCLUSIONS}

We have demonstrated a data-based optimization analysis in the resource allocation perspective on the contribution of Zakat to support providing capitals for poverty reduction-based SME development in Indonesia.

In general, all case studies on the Zakat institutions in Indonesia showed needs of improvements in their recent strategies on the programs aimed to allocating the collected fund resources to be delivered to the respective beneficiaries, which were indicated by the changes in efficiency and effectiveness scores in the optimal reallocation evaluation.

Lower ratio allocated fund per beneficiary number unit (or "productivity in philanthropy") attached to the charity-based delivery programs could trigger negative impacts in term of decreases of both fund and beneficiary allocations for the povertyempowerment-based programs, which would have significant impacts on weakening the empowering poverty in term of the poverty reduction efforts. To resolve this problem, the zakat institutions, even the government as regulator, might have a clear focus on the poverty-empowerment-based programs in providing needed capitals for poverty empowerment. They are expected, for example, to create an upper threshold or a certain constraint for fund allocation of the charity-based delivery programs. In other side, they should also encourage enhancing the "productivity in philanthropy" of programs that develop entrepreneurship in term of poverty reduction efforts. These two points would become crucial hypotheses for next researches that could fulfill a gap of knowledge on this topic recently.

\section{ACKNOWLEDGEMENTS}

The first author would like to express thankfulness to the BAZNAS for the Research Grant in 2018 provided to this work as a part of Dissertation project in the Doctoral Program of Management Science, the Faculty of Economics and Business, in the University of Padjadjaran, BandungIndonesia.

\section{REFERENCES}

Aspen Network of Development Entrepreneurs (2012). Small and Growing Businesses: Investing in the Missing Middle for Poverty Alleviation Literature Review. The ANDE Research Initiative

Asuru, S.I. (2015). The New Philanthropy, Poverty Reduction and Rural Development: A Case Study of Alliance for a Green Revolution in Africa (AGRA) in Ghana. Journal of Government and Politics, 6(1), 18-30. http://dx.doi.org/10.18196/jgp.2015.00 03

Berlin, G. (2008). Poverty and Philanthropy: Strategies for Change. Prepared for the Charles Stewart Mott Foundation "Defining Poverty Reduction Strategies" Project

Charnes, A., Cooper, W.W., Lewin, A.Y. 
Seiford, L.M. (1997). Data Envelopment Analysis: Theory, Methodology and Applications. Kluwer Academic Publishers, Massachusetts, ISBN 0-7923-9480-1, $2^{\text {nd }}$ printing,

Cumming, D.J. \& Johan, S.A. (2014). Venture Capital and Private Equity Contracting, Second Edition: An International Perspective, Elsevier Inc, United States, ISBN 9780124095373, pp. 3-4.

Dees, J.G. (2008). Philanthropy and Enterprise: Harnessing the Power of Business and Social Entrepre-neurship for Development. Innovations / summer 2008, 119-132.

Golany, B. \& Tamir, E., (1995). Evaluating Efficiency-Effective-ness-Equality Trade-Offs: A Data Envelopment Analysis Approach. Management Science, 41(7), 1172-1184, DOI: 10.1287/mnsc.41.7.1172

Hisrich, R.D., \& Peters, M. P. (2002). Entrepreneurship. Boston. Mass.: McGraw-Hill/Irwin, c2002 (ie 2001), 5th ed., ISBN 0072314060, $663 \mathrm{p}$.

Kasri, R.A. (2016). Effectiveness of Zakah Targeting in Alleviating Poverty in Indonesia, Al-Iqtishad: Jurnal Ilmu Ekonomi Syariah (Journal of Islamic Economics), 8(2), 169-186, P-ISSN: 2087-135X; E-ISSN: 2407-8654

Koshy, P. \& Prasad, V.N. (2007). Small and Micro Enterprises: A tool in the fight against poverty. Munich Personal RePEc Archive, No. 22827,

Available at http://mpra.ub.unimuenchen.de/22827/

Lim, J. \& Jaunders, A. (1990). Initial Public Offerings: The Role of Venture Capitalists. The Research Foundation of the Institute of Chartered Financial Analysts, p. 14, ISBN 0943205077

Mamman, A., Kanu, A.M., Alharbi, A., Baydoun, N. (2015). Small and
Medium-Sized Enterprises (SMEs) and Poverty Reduction in Africa: Strategic Management Perspective. Cambridge Scholars Publishing, Newcastle upon Tyne, ISBN 978-1-4438-7264-5

Pennypacker, J. S. (2008). Portfolio Resource Management: The Most Significant Challenge to Project Management Effectiveness. Paper presented at PMI® Global Congress 2008-North America, Denver, PA: Project Management Institute.

Runeson, P., \& Höst, M. (2009). Guidelines for conducting and reporting case study research in software engineering. Empirical Software Engineering, 14(2), 131-164. DOI: 10.1007/s10664-008-9102-8

Vandenberg, P. (2006). Poverty reduction through small enterprises: Emerging consensus, unresolved issues and ILO activities. SEED Working Paper No. 75, International Labour Organization, Small Enterprise Development Programme, Job Creation and Enterprise Development Department, International Labour Office - Geneva, ISBN 92-2-118200-2.

Yin, R.K. (2003). Case Study Research: Design and Methods. Sage Publications, $3^{\text {rd }}$ ed., London

Yumna \& Clarke (2012). Integrating zakat and Islamic charities with microfinance initiative in the purpose of poverty alleviation in Indonesia. 8th International Conference on Islamic Economics and Finance. Center for Islamic Economics and Finance, Qatar Faculty of Islamic Studies, Qatar Foundation.

\section{Vita Sarasi}

Faculty of Economics and Business, Universitas Padjadjaran vitasarasi17968@gmail.com 
Ina Primiana

Faculty of Economics and Business,

Universitas Padjadjaran

ina.primiana@fe.unpad.ac.id

Dian Masyita

Faculty of Economics and Business,

Universitas Padjadjaran

dian.masyita@fe.unpad.ac.id

Yunizar

Faculty of Economics and Business,

Universitas Padjadjaran

yunizar@fe.unpad.ac.id 